6-1-2005

\title{
Consuming Globalization: Youth and Gender in Kerala, India
}

Ritty Lukose

ralukose@gse.upenn.edu

Follow this and additional works at: https://repository.upenn.edu/gse_pubs

Part of the Social History Commons

\section{Recommended Citation}

Lukose, R. (2005). Consuming Globalization: Youth and Gender in Kerala, India. Retrieved from https://repository.upenn.edu/gse_pubs/30

Reprinted from Journal of Social History, Volume 38, Issue 4, June 2005, pages 915-935.

Publisher URL: http://muse.jhu.edu/journals/jsh/

This paper is posted at ScholarlyCommons. https://repository.upenn.edu/gse_pubs/30

For more information, please contact repository@pobox.upenn.edu. 


\title{
Consuming Globalization: Youth and Gender in Kerala, India
}

\author{
Abstract \\ In much popular discourse, a short-hand way to mark the advent and impact of globalization is to point to \\ the evidence of "global" youth consuming practices and symbols in often remote corners of the world: \\ during the 1990s, for example, the popularity of the basketball star Michael Jordan and his team the \\ Chicago Bulls in the slums of Brazil and in rural villages in Africa, the spread of hip-hop music around the \\ world, and the popularity of McDonalds among young people in China. These examples have a theory of \\ globalization and youth embedded within them. Youth is seen as a consuming social group, the first to \\ bend to what is understood to be the homogenizing pressures of globalization, a globalization \\ fundamentally tied to Americanization. Youth consumption practices become an index of the presence \\ and reach of globalization. \\ Disciplines \\ Social History \\ Comments \\ Reprinted from Journal of Social History, Volume 38, Issue 4, June 2005, pages 915-935. \\ Publisher URL: http://muse.jhu.edu/journals/jsh/
}




\section{CONSUMING GLOBALIZATION: YOUTH AND GENDER IN KERALA, INDIA}

By Ritty Lukose

\author{
University of Pennsylvania
}

\section{Introduction}

In much popular discourse, a short-hand way to mark the advent and impact of globalization is to point to the evidence of "global" youth consuming practices and symbols in often remote corners of the world: during the 1990s, for example, the popularity of the basketball star Michael Jordan and his team the Chicago Bulls in the slums of Brazil and in rural villages in Africa, the spread of hip-hop music around the world, and the popularity of McDonalds among young people in China. These examples have a theory of globalization and youth embedded within them. Youth is seen as a consuming social group, the first to bend to what is understood to be the homogenizing pressures of globalization, a globalization fundamentally tied to Americanization. ${ }^{1}$ Youth consumption practices become an index of the presence and reach of globalization.

Such short-hand ways of indexing the salience of contemporary forms of globalization as a cultural force obscure the ways in which new global cultural forms are inserted into long-standing struggles over the meanings of modernity in many postcolonial locations. ${ }^{2}$ While attention to globalization as a new cultural force is crucial to understanding the changed cultural, political, and economic conditions under which much of the postcolonial world now struggles, situating globalization within long-standing histories of the production of modernities around the world is in turn crucial to interrogating claims about new-ness, homogenization, and cultural force that the discourse of globalization itself produces. As I will argue below, in the context of India, an understanding of the dynamic relationship among youth, consumption, and globalization requires an interrogation of the conditions under which young people engage new spaces of consumption. These conditions are profoundly shaped by colonialist and nationalist categories such as "tradition/modernity" and "public/private" which structure the ways in which young men and women negotiate new consumer identities and spaces.

The equation between youth, consumption, and globalization is also made within scholarly discourse. Though this discourse tends to challenge the notion that globalization is about the Americanization of the world, all the difference and deviation from a homogenized understanding of globalization is folded into a notion of a resistant "local", in opposition to the "global", in ways that produce overly dichotomous and somewhat caricatured notions of both what globalization entails and the complexity of what might constitute "the local". For example, globalization, as a political, economic, and cultural force, operates as much through the production of difference as sameness. Likewise, the "local" might collude with and resist structures of globalization, partaking of hegemonic 
forms of cultural nationalism that both dominate and marginalize, as is the case with Hindu nationalism in India. Further, folding the difference and deviation from a homogenized understanding of globalization into some undifferentiated notion of the "local" leaves unmarked the nature of a specifically postcolonial difference. This is especially true with respect to understandings of consumption within cultural studies and anthropology.

Cultural studies of youth have highlighted the role of consumption practices in the formation of youth cultures. ${ }^{3}$ These studies have focused on the ways young people deploy music and clothing styles in order to form subcultural youth identities which are seen as acts of resistance against a dominant culture. This body of research has opened up the possibility that consumption does not simply produce victims of capitalist hegemony, but is a site for a complicated mediation of youth identities. More recently, this focus on youth cultural practices has extended beyond the Euro-American context, to link a concern with globalization, youth cultural studies, and spatiality in non-Western contexts. ${ }^{4}$

The anthropology of globalization has also been marked by a focus on consumption. ${ }^{5}$ This has led to significant overlap—if not identity—-between what one might call the anthropology of globalization and the anthropology of consumption, though clearly, they are not reducible to each other. ${ }^{6}$ Arguably, it is impossible to do a contemporary study of some aspect of "consumption" without reference to some aspect of "globalization" and vice versa-indeed, it is argued that consumption is a privileged site for the study of globalization.

This renewed focus on consumption as a site for the exploration of this moment of globalization dovetails with the rise of cultural studies and its influence on anthropology. The rise of cultural Marxism, its consolidation into cultural studies, with an important and early focus on youth, and its influence on anthropology has also led to the privileging of consumption as an object of cultural analysis. ${ }^{7}$ This privileging of consumption is founded on an argument with(in) Marxism about the relative importance vis a vis production of the realm of exchange, advertising, and consumption in the economic, social, and cultural processes that make up the changing historical dynamics of capital. ${ }^{8}$ Much work in the cultural studies and anthropology of consumption has been devoted to exploring this hitherto undervalued and neglected domain of social life, arguing its importance for understanding identity formation under the intersecting frames of colonialism, nationalism, and capitalism. ${ }^{9}$ This body of research has opened up the possibility that consumption does not simply produce victims of capitalist hegemony, but is a site for a complicated mediation of identities.

Rather than view consumption as an already existing, readily available set of social practices that need to be examined and deciphered, I suggest that the terrain of consumption cannot be so easily assumed. The above approach naturalizes consumption as an already existing, readily available set of social practices. Secondarily, questions are posed about the presence or absence of agency, the mediation of identities, and the relationship of this already existing domain to other domains (e.g., production). However, instead of examining "agency" or "identity" per se or attempting to discern the relative importance of consumption vis a vis production, I would like to begin by examining the space of consumption itself. While there is no doubt that consumption as a structured field of practice "exists", it is also itself an object-something to be produced 
through discourse, practice, and imagination. ${ }^{10}$ As Beng-Huat states for East Asia, much theorization and research on consumption focuses on identity politics and comes out of an argument about the importance of consumption visà-vis high/low debates about culture within the Euro-American context. ${ }^{11}$ The field of consumer practices is often taken for granted. While the identity politics of consumer practices is certainly crucial, especially for the politics of youth and generation, the ideological context within which that politics is played out is quite different. Within the debates I analyze below, discourses of consumption insert themselves into the cultural-ideological terrain of postcolonial states and societies, struggling with the legacy of colonialism and anti-colonial nationalism, as they intersect with a new global order. This terrain is marked by debates about Westernization, tradition, and modernity that emerge out of colonial modernity and are newly reconfigured under new conditions of globalization. Drawing on the cultural history of South Asia, I would also argue that the terrain of preoccupation with Westernization, tradition, and modernity is a profoundly gendered one, in which the place of women along the public/private and tradition/modernity binaries becomes key to understanding the dynamics of this cultural-ideological terrain. Consumption, as "social practice" or "everyday life", operates in and through these political fields.

This article examines how new, globally-inflected patterns of consumption among young people in the state of Kerala, South India (through clothing practices, movies, and the staging of beauty pageants) are reconfigured in relation to the colonialist and nationalist projects concerned with the place of women within the public/private and tradition/modernity dichotomies. Drawing on feminist cultural analysis that has renewed its interest in consumer culture, it is concerned with youth as a gendered category of consumption. Rather than see consumption as singularly a site of patriarchal domination and the commodification of women's bodies, feminist writers and cultural historians, echoing arguments in youth cultural studies and the anthropology of consumption, have investigated the ways in which consumer culture is a complex site of female participation and constraint, enjoyment and objectification. ${ }^{12}$ These cultural analyses focus on what women and girls do with consumer goods and how commodities give rise to meaning-making processes which are frequently at odds with the intended meanings and usages, leading to ascriptions of "resistance" and "agency" to female consumers. Rather than focus on the presence or absence of agency, I am more interested in elucidating the cultural-political terrain into which consumption as an objectified field of practice is inserted. By paying attention to this terrain, it becomes possible to examine the contradictions of fashion for young women and men who are both objects of commoditization and subjects of consumption. I examine the ways in which a modern nationalist patriarchy which placed women in the private, but allowed them to traverse the public through the deployment of class-inflected gendered demeanors and feminine habitus, confronts the patriarchy of a globalizing capitalism through new forms of consumption. In turn, this analysis seeks to understand how commodified masculinities are differentially related to this same public/private nexus.

I locate consumption as a field of practice within larger discursive domains, at both the national and regional level, which contest the meaning of globalization in ways that produce and circulate highly gendered constructions of consumer 
agency. I begin with a discussion of globalization at the national level, laying out youth, fashion and beauty as a highly contested discursive field in which globalization is contested at this national level, revealing the category of youth as a potent site of gendered consumer objectification and agency. Drawing on ethnographic material on gender, youth, and consumption in Kerala, I then trace the gendered terrain that underlies this field of consumption. I lay out the gendered tropes of the "traditional" and "modern" girl as a key binary opposition which structures this gendered space, a space differently configured for young men. Negotiating the space of consumption under new conditions of globalization entails traversing a gendered terrain of masculinities and femininities in way that reveal the link between youth, consumption, and globalization to be a fraught and contradictory one.

\section{Contesting Globalization}

Initiated in the early 1990s, economic liberalization policies, reducing tariffs and duties on imported goods, opening up state controlled industries to the private sector, transforming the banking and investment sector, to name a few of the economic reforms that this liberalization entailed, have intensified the globalization of the Indian economy, in the realms of both production and consumption. In this context, several formulations have marked the rise of consumption as a new terrain for the reconfiguration of national identity in the globalizing 1990s, supplanting the national, developmental citizen of the postindependence national-socialist Nehruvian state. ${ }^{13}$ Deshpande identifies as the clearest representative of this new "cosmopolitan consumer" the Non-Resident Indian (NRI) - a category of the Indian state that refers to those living and working abroad—as a kind of modern mythological hero for the globalizing Indian middle classes. ${ }^{14}$

One of the ways in which globalizing capitalism intersects with local structures of meaning and power is by producing culturally strategic images of consumer agency. Non-Resident Indian (the NRI) is just such a category, initially generated from the Indian nation-state's encounter with a variety of diasporic Indian realities. First, NRI is a bureaucratic, banking category aimed at attracting investment capital and foreign reserves from Indians living and working abroad. The most concrete manifestations of this category are the NRI accounts and financial schemes in banks. In Kerala, these accounts have consistently comprised about 25 percent of the state's domestic product for the last 25 years. ${ }^{15}$ But the NRI formation is not simply reducible to remittances. The NRI in India is also a cultural category, a consumer lifestyle that is selectively construed as upper-caste and upper-class, for fashioning a new kind of market-driven citizen in India. The fashioning of the new consumer citizen requires the material possibility that one can live an NRI lifestyle, that one can be "NRI" without ever leaving India.

The new figure of the globally-oriented Indian consumer is fashioned in and through specific images of consumer agency. Recent scholarship on advertising, television, and film in India have highlighted the ways in which globalizing capital operates through the production of specific and various sites of consumer desire and agency, marked by caste, region, community, age, gender, and class. ${ }^{16}$ 
A key figure in this articulation of global capital with specific sites of consumer agency is the young, westernized, female.

The importance and salience of the young, westernized female has a longstanding history within colonial and nationalist modernity. Partha Chatterjee and feminist cultural analysts of South Asia have argued that anticolonial Indian nationalism created homologous dichotomies such as Indian/Western, spiritual/material, private/public, tradition/modernity, home/world, inner/outer, and female/male in order to produce a nationalist identity that could be seen as separate from and superior to Western domination. ${ }^{17}$ This nationalism rested on a modern, nationalist patriarchy when it placed women within the private, inner, spiritual home of the nation. The disruptive figure of the modern, westerneducated, woman in public was stabilized and rationalized through a construction of middle-class women who could traverse the nationalist public if they carried their "essential femininity" with them. This essential femininity, a gendered bodily habitus, variously identified as "respectability" and "modesty", involved the creation of appropriate dress, activity, and a set of exclusions that constructed working-class/low-caste women as coarse, vulgar, and crude. ${ }^{18}$ Therefore, this class-specific, gendered habitus would operate across the public/private divide. But the contradictions and ambivalences for women, who traverse the public, makes clear that such gendered bodily demeanors are problematic, especially when written onto dichotomies such as tradition and modernity, Indian and Western. The constant threat of sexualization makes the woman in public an unstable and volatile presence.

New spaces of consumption are structured by constructions of tradition/ modernity and public/private in ways that mark them as new, middle-class spaces, gendered in particular ways. While the colonial and earlier nationalist construction of the woman in public was one who was educated, respectable, and modest, spaces of consumption marked by more contemporary forms of globalization portray a more aggressive, confident, sexualized, and aggressively public figure. This kind of figure has also had its antecedents, in the figure of the vamp, for example, in popular cinema. However, while the former is sexualized, she is not often understood to be confident, aggressive, and entitled to her place in the public, which more contemporary, dominant representations of young, globalized Indian femininity reveal. ${ }^{19}$

A good example of the production of such a consumer identity is Channel V, India's counterpart to MTV. Modeled on the latter, Channel V has a decidedly "Asian" flavor. Headquartered in Hong Kong and Bombay, programs focus on Filipino, Japanese, Indian, and sometimes Arab pop music. Many shows marketed for a specifically Indian audience are produced within India, and they include a complex of Hindi film song countdowns, the burgeoning Indian English/Hindi pop not tied to films, and pedagogical shows teaching the history of Euro/American rock and classic Hindi film songs for younger audiences, along with contemporary western pop music videos. What is interesting about these shows are the veejays, or hosts. While there are exceptions, the most prominent hosts were Sophiya, a British Indian, Ruby, a Canadian Indian, and Kamla, a US Indian. Speaking in their respectively accented Englishes, with occasional forays into exaggeratedly accented Indian English and broken Hindi for comic effect, they personify and market the NRI lifestyle for the new consumer in India. 
Between music videos, Ruby, followed by a roving camera, can be seen roaming the streets of Mumbai or on the beach encountering a woman in tattered clothes selling fish. Ruby approaches and in Hindi asks what her name is, where she is from and what she is doing. The woman laughs and says "I don't know." The exchange continues with Ruby asking her to say something for the camera. The woman is silent. The camera moves to the basket of fish, to the others selling fish on the beach, accompanied by Ruby's chatter. This species of comic relief is commonly interspersed between music videos. What this serves to do is reinscribe and produce the identity of the middle-class consumer subject in contradistinction to that of the common working masses. The NRI lifestyle embodied in Ruby's speech and fashion, and in her alienation from the woman fishmonger only highlights her distinctive, highly gendered and class-specific lifestyle choice. Further, the implicit distinction between Ruby as a young woman and this older woman points to the ways in which Channel V seeks to portray and valorize a youthful "public woman", comfortable roaming and traversing public places, the streets and beaches of Mumbai, but doing so in an assertively consumerist fashion. This public woman is circumscribed by her allegiances to the feminine fashions of the western clothing industry. The crucial point to note is this: these veejays are not white Canadians, Americans, or Britons. On the other hand, neither are they children of less affluent migrants to places like the Persian Gulf. The selective appropriation of the diasporic experience of migrants to industrialized, "first-world" destinations, marks not only the class character of that particular diaspora itself, but points to the class-specific, highly gendered stakes of fashioning a new consumer citizen within India.

Another example of this kind of fashioning is the burgeoning beauty industry in India. Key moments in the celebration of India's ascendance to a new role in the global economy include the figures of Sushmita Sen, winner of the Miss Universe pageant in 1994, and Aiswarya Rai, winner of the Miss World contest in 1995, their bodies embodying India's worth on the global stage, their tiaras crowning India's attractiveness in the global market. In fact, with the crowning of Lara Dutta as Miss Universe 2000, India has produced its fifth international beauty contest winner in the last six years, becoming like Venezuela and the US, a major "beauty machine". ${ }^{20}$ The beauty pageant industry exploded in India in the 1990's. Almost every school, college and kindergarten holds a contest. Delhi is estimated to have had 21 major pageants last year. ${ }^{21}$ Beauty pageants are held by cities, suburbs, and housing colonies. As Pradeep Guha, national director of the Femina (a major women's magazine) Miss India contest and executive director of the Times of India group which owns the Miss India franchise, states, "It's a sociological phenomenon." ${ }^{22}$ At the more elite levels, a vast structure of beauty experts and technicians groom young Indian women for modeling careers and beauty pageants on the global stage. ${ }^{23}$

The Miss World pageant of 1996 is particularly noteworthy. Held in Bangalore, South India, the Miss World pageant crowned its queen, Irene Skliva, an 18-year-old model from Greece. ${ }^{24}$ Other than profits for the Indian event manager (the Amitabh Bachan Corporation, Ltd.) and, moreover, for the Indian government which provided crucial support, hosting the Miss World pageant in Bangalore was a chance to stage India to the world. The state-owned television network Doordarshan broadcast the pageant live and the organizers claimed In- 
dia had been "showcased" to 2.5 billion viewers in 150 countries. Prior to the actual pageant as well as during breaks in the posing and questioning of the 88 contestants, India was presented to the audience as a spectacular mix of "tradition" and "modernity". There were dancers like Mallika Sarabhai and film actresses Juhi Chawla and Shobana performing classical Indian dances such as bharatnatyam, mohiniyattam, and manipuri. Indian pop star Alisha Chinai sang. A Kathakali dance troupe from Kerala decorated the stage, amidst props that recreated the great ruins of Hampi. And Prabhu Deva, the pop music dance sensation of the new Tamil cinema, worked his magic.

The staging of the pageant in the city of Bangalore is likewise significant. Touted as the Silicon Valley of India, the city is both a representation and the premier embodiment of a newly liberalized Indian economy and globalized Indian culture. Drawing on local, "traditional" elements (Bangalore is the closest major city to the ruins of Hampi), the pageant organizers sought to stage the contrast between an ancient civilization and a modern one by highlighting Bangalore as a key site of globalized economic production and a globally-oriented middle class in India. More specifically, the Bangalore pageant was co-hosted by a white Australian man and a Non-Resident Indian woman-the aforementioned Canadian-born Ruby Bhatia Bali, host on Channel V. On the global stage of the Miss World contest, Ruby, with her Americanized accent, "showcases" a highly westernized, aggressively public, globalized femininity that is reinscribed as Indian.

This reinscription of the Indian and the other elements of the "traditional" and the "modern" apparent in the staging of this beauty pageant reveals the dynamics of producing locality on a highly globalized stage. However worldly the six Indian Miss Universes and Miss Worlds become, what matters is that they are Indian Miss Universes and Miss Worlds, evidenced by the way in which these Indian beauty queens who have proven themselves on the international arena are welcomed back home with much national fanfare and celebration. ${ }^{25}$ What circulates on the global stage of beauty is a form of commodified femininity, supported and abetted by global multinational corporations and their desire for new markets, which must always reference some form of locality in order to produce those markets. In the racialized politics of international beauty pageants, the recent upsurge in winners from Third World countries such as India and Botswana have many pointing to the development of new markets for multinational cosmetics companies such as Avon and Proctor and Gamble. ${ }^{26}$ The forms of this commodified femininity take on a homogenizing characterthe often-heard complaint that Western norms of beauty based on thinness and light skin are reshaping "indigenous" norms of beauty not only in the beauty business but in the important film industry as well. How these globalizing norms intersect with longstanding ideas about fairness of skin, tied to caste politics, for example, have yet to be studied. As has been often pointed out, globalization produces differentiation as much as homogenization. ${ }^{27}$

If Bangalore is emblematic of the new globalized India, it has also been the site of a contested politics of globalization. These include protests by a Karnataka peasant movement against Cargill, a multinational seed company based outside Bangalore and the protests against the introduction of Kentucky Fried Chicken to Bangalore. Other flashpoints have included protests against a Coca- 
Cola bottling company in Plachimada, Palakkad District in Kerala, the multinational accused of contaminating the water supply. Drawing from the political spectrum, including the left and the Hindu nationalist right, the politics of antiglobalization utilizes anti-colonial, economic and cultural nationalist positions, to protest the inroads of globalization. ${ }^{28}$ However, none of these protests was as large as the fractious protests against the Miss World pageant itself.

The mobilization over a two-month period of 12,500 police and paramilitary personnel from city, state, and central security forces was the largest use of state power to help what was essentially a multinational, private, commercial venture fend off widespread protests from a diverse array of political organizations. The protests came essentially from two sides. Women's groups on the Hindu right opposed the pageant on the grounds that it would import a decadent western culture which undermines "Indian culture". In the words of Premila Nesargi, a lawyer and member of the Hindu right, Bharatiya Janata Party (BJP):

There is only one common culture of Indians, irrespective of caste, creed, and sex. Our culture cannot be taken away by others, invaded ... In India women are not meant to be sold. Women are not treated as a commodity available for sale in the bazaar. If she sells herself, either her flesh, or body or beauty, she is offending every law in India. Commodifying a woman is wrong. You cannot reduce her to the status of a chattel. Beauty cannot be sold. ${ }^{29}$

The left-affiliated and independent women's groups distinguished themselves from the more conservative critics whom they felt focused on a unitary and conservative notion of "Indian tradition", "a euphemism for the subordination of women." Rather they focused on the liberalization of the economy and the growing influence of multinational corporations which they argued had created a climate in which events like beauty contests thrive, events that demean and commodify women. Brinda Karat, General Secretary of the left-affiliated All India Democratic Women's Association, (AIDWA), brings a class and gender perspective to bear on the pageant:

Copycat contests are being organized in neighborhoods across the country. The growing obsession with "looking good" is not a reflection of the growing confidence of the independent-minded "modern miss" ... nor is it a reflection of "free choice" ... [T] his constitutes oppressive pressure on young middle class women and distorts their self-worth. The processes of a new type of socialization driven by the market mantra impose stereotypes that are as oppressive and degrading for women as the earlier stereotype of the pativrata ... [W] [ith the advent of policies of globalization and liberalization there has been an unprecedented increase in the efforts of the beauty industry to create a market for its products ... There are clear links between globalization and the accelerated commodification of women ... The contest was an insult to the vast masses of India's women, who struggle to make both ends meet and are deprived of the right to a decent human life. If there is beauty it is in their courage. ${ }^{30}$

I provide this extended discussion of this pageant, the protests, and the issues at stake in order to highlight several points. One, the fact that India is experiencing a period of economic liberalization in both production and consumption. This analysis of the pageant reveals the ways in which consumption is 
not only one half of a capitalist system, but a discursive site for contesting and imagining the Indian nation. Two, this discursive site, evident in various media, that markets and constitutes a consumer-driven middle class oriented towards the global economy is crucially imagined through the bodies of young, middle-class, females. Three, the discourse rests on notions of "tradition" and "modernity". Finally, a contested cultural politics of globalization involves the demonization of consumption, a consumption crucially linked to the commodification of women's bodies. The Hindu right and left-feminist perspectives are obviously different in important respects. The conservative position rests on a deployment of "tradition" that masks gender oppression and patriarchy within as well as outside "India". Like cultural nationalists of the later 19th century that Chatterjee has discussed, these nationalists of the Hindu right place women under the sign of a privatized tradition that must be defended against the corruption of Western materialism. The left-feminist perspective rejects "Indian culture" as patriarchal. Yet, it also rejects simplistic identifications of "modernity" with the space of women's freedom. This "modernity", rooted in the structures of patriarchy and capitalism, collaborates with the patriarchy of continuously reinvented "tradition" to produce new forms of gender oppression. Both positions, however, are operating in tandem in their rejections of the commodification of women. For the Hindu right, this commodification is associated with an invasive, alien, foreign culture. For the feminists, it is associated with an imperialist form of capitalist oppression. This is an oppression that differentially affects the "modern miss" and those who cannot consume beauty products because they are trying to "make both ends meet".

Critically examining these protests, Mary John states that left-wing feminist protesters could be so easily grouped with BJP women's groups because the critique of the inroads of multinational capital into the domestic consumer market appeared analogous to campaigns calling for the protection of Indian Womanhood and culture. ${ }^{31}$ Put another way, critiques of capitalism, which often depend on spacio-temporal grids distinguishing Indian and Western, tradition and modernity, are often produced on the surfaces of women's bodies. If a feminist critique of capitalist consumerism is to distinguish itself from nationalist anticapitalist critiques, it must produce a critical account of the production and circulation of these spacio-temporal grids, so as to reveal and interrogate the burden of locality placed on femininity. ${ }^{32}$ John further suggests that we begin with the localized and sedimented character of the beauty business in India. ${ }^{33}$ Protests of the pageant took the form of mock "queens" crowned as "Miss Disease" and "Miss Starvation" in order to point to basic priorities such as poverty and healthcare from which the state had been retreating while providing tremendous support for this private venture. This form of protest, while valuable, erases the critical task of examining beauty as a structure of aspirations and anxieties and also erases the need to address a feminist politics to young women, the "modern miss".

In the material to follow, I examine youth as a gendered category of consumption in the southern state of Kerala, in a way that pays attention to the production of youthful femininities and masculinities. I emphasize how notions of public and private, tradition and modernity, structure new spaces of consumption, in ways that have differential consequences for young men and women. This 
is not simply an argument about the relevance of the "local" for the "global", but rather an attempt to delineate the ways in which a postcolonial location apprehends globalizing capital.

\section{Youth and Consumption in Kerala}

Keralites began to go across the Arabian Sea in large numbers to the Persian Gulf following the boom in oil production in the early 1970's. Large-scale migration from Kerala to other parts of India, Europe, and the United States, as well as the Gulf, is partly due to the high rate of unemployment in the region. While the state has been relatively successful at redistributing healthcare, educational, and other resources, it has been relatively unsuccessful at creating jobs. It has one of the highest rates of unemployment in the country, sometimes proclaimed to be 30 percent. ${ }^{34}$ Migration to the Persian Gulf is by far the most important and intensive. This traffic of labor and money has produced a situation in which the people and the state of Kerala are heavily dependent on the global economy and incorporated into its social, cultural, and material movements.

The evidences of NRI remittances are everywhere. Land prices have shot up due to intense land speculation by migrants eager to build their "Gulf houses". Huge, upscale flat complexes now pepper the landscape, marketed as fashionable housing for Gulf returnees and for others who can afford them, leading to dire predictions about the consequences of a new "flat culture". In villages, televisions, refrigerators, motorcycles, and new houses proclaim a family's Gulf connections. This incorporation into the transnational traffic of labor and money has produced a cultural politics of globalization within Kerala, written, as I will argue, on the female body.

Within this context, whether it be the preponderance of fashion shows, beauty contests, or "fancy dress" competitions, the association between youth and style or fashion is a ubiquitous one. Within popular media and everyday discourse, the link between youth, consumption (marked by a concern with fashion), and globalization is often made. A key figure in this link is a form of commodified masculinity, marked by a kind of ephemeral hyper-fashion that celebrates physicality, freedom, and romance. In an article about the important Tamil film Kaadalan (Loverboy), Dareshwar and Niranjana point to new forms of youthful, commodified masculinity produced within this new moment of liberalization, a film that was enormously important in creating a new youth style and aesthetics, marked by a clothing (baggy pants, long oversized shirts, sneakers, ponytails), rap music, and Michael Jackson dance moves that have come to be the referents for producing a fashion-conscious sensibility among low-caste young men. ${ }^{35}$ The cassettes of these movies and that of ragga musician Apache Indian, a UK-born Indian DJ popular in the UK, the Caribbean, and India, were the hottest-selling items at many music stores. Perhaps the hit of the 1990's, this film marked the beginnings of a new aesthetic in film, combining MTV-style shots, dance sequences, and rap. Set in a college-student milieu, Dareshwar and Niranjana argue that the film reconfigures the young dalit (low-caste) male body to mediate globalization, the violence of the state, and the demands of tradition. The body of the lower-caste male youth, under the sign of "fashion" indicated by his playful desire for blue jeans and sneakers, is being refashioned as urban and 
consumerist. This kind of fashioning was usually reserved for the upper-caste male body, as seen in the important and popular films of Mani Ratnam such as Roja and Bombay, in which the space of liberalization is produced through the bodies of upper-class/caste Hindu forms of masculinity and femininity. Previously, it was under the rubric of the "folk" and the "rural" that the lower caste body had been configured. This film marks an important moment, where globalization and its signifiers attach themselves to the body of the male lower caste "youth".

An important concept in understanding the association between youth, masculinity, and consumption is a youth slang word, chethu. ${ }^{36}$ While it can refer to the stylish nature of many commodities and in some sense can refer to the notion of "being fashionable" in general, it refers most significantly to a kind of commodified masculinity. If a male is dressed in a new pair of jeans and fancy sneakers, he is usually referred to as chethu, a word which literally refers to the traditional, low-caste occupation of toddy-tapping and the tapper's knife, and figuratively means "sharp", "cool", "hip", or "shine", referring to something like the "cutting-edge". A fancy car, a stylish house, or a new motorbike are all chethu. A store dedicated to selling fashionable clothes was named Chethu. A fashionable young man is chethu, but rarely is the term applied to women. If a woman dressed in a particularly fashionable way (especially if she were wearing a western-style skirt), she was said to have gema, a term which connotes arrogance-something between being a "show-off" and being "stuck-up". A young man was rarely described as having gema.

The sense of this term was playfully interpreted for me during a long, rambling interview with one of the more fashion-conscious young men in the college in which I conducted fieldwork. I never saw Devan in anything but jeans or baggy pants, a long oversized shirt that went down to his knees, sneakers, and often a baseball cap with the word "Boss" emblazoned on it. Somewhat the class clown, he was a curious mixture of anxieties. He came from a lower middleclass Izhava ${ }^{37}$ family in town. As he tells it, he was a good student during school, having gone to a well-disciplined Christian school. College was a different story. He didn't want to do engineering or medicine, as his parents wished. He said he found them boring. He had an interest in the Civil Service. That meant then something like History, English or Political Science. History was just the study of dates, so he dismissed that. If one wanted to succeed in the Civil Service exams studying English, one needed to go to something like Doons School or Delhi Public School. ${ }^{38}$ It seemed a bad bet given where he was coming from: a marginal college, in a backwater town, in southern Kerala. That left Political Science.

But he was not very serious about college. He blamed a bad crowd he fell into when he first got to college, going to three or four movies a week, hanging out at the beach, and spending time at the public library reading Mills and Boons romance novels for titillation. He was affectionately known by his friends as "Mr. Quote" because as I found out, he punctuates much of his speech with quotes in English, from Dale Carnegie to Gandhi. Explaining the effect of falling in with the wrong crowd, Devan quotes, "You are the company you keep." On the importance of friendship, he quotes Gandhi: "True friendship is a rare one. It is the identity of two souls." Caught between his bourgeois aspirations and his 
desire to have fun, Devan presented a playful, anxious set of observations on his life and the meanings of being young. He begins by telling me what he thinks you need in order to count, or matter in his college. He states:

It's the chethu style, jeans, a Yamaha bike [he only had a bicycle]. You need to have 6 or 7 jeans, Killer jeans [a brand name]. You need four or five cotton shirts, 3 to 4 T-shirts, a well-groomed, chethu, smart look. A bike. You must have a bike.

Having delineated the minimum material requirements for a chethu style, Devan goes on to delineate the masculine persona that signifies and is signified by this style of commodified masculinity. He goes on to delineate some fine nuances in this chethu style. A less common term often used interchangeably with chethu was ash-push — a term that many said came from English, or the sound of English as it was heard by Malayalam speakers.

Its just a matter of intensity. Ash-push is much more intense than chethu. Ashpush ... a life that is in the chethu way, you enjoy life. You go to a beer parlor and have beer, that is ash-push. A Yamaha bike, money in the hand, a line [slang for a relationship with a girl], that's it, in between you go to a beer parlor and you sip two beers, you have plenty of friends, you enjoy life. You enjoy the life. You don't care about what has happened yesterday. You don't care what will happen tomorrow. You are always happy. That is chethu.

This notion of chethu encompasses within it several aspects of a youthful, commodified masculinity that brings together clothing styles, status, and an attitude about the world based on ephemerality and some notion of fun.

Devan's narrative reveals the aspiration and anxiety that underlie his desire for Yamaha motorbikes, Killer jeans, $t$-shirts, and beer parlors. The desire for new globally-inflected commodities (new motorbikes, jeans, etc) on the part of young men in Kerala is not simply an index of the reach of globalization as such. These commodities and the desire for them emerge out of and are re-situated within consumer identities that reveal the specificity of the locations out of which this desire emerges. Located in a small, backwater town in Kerala, Devan fashions a notion of the "good life" which may not be available to him in concrete material terms, but nonetheless, informs his own self-fashioning as a "chethu" figure, an irreverent, happy-go-lucky young man, cruising the public in search of fun.

\section{Masculine Anxieties}

So far, I have discussed the relationship among youth, consumption, and masculinity in delineating the apprehension of globalized cultural forms. What is the relationship between femininity and these globally-inflected spaces of consumption? Once again, I will delineate the structures of representation that mark these new spaces through an analysis of a typical of youth film, marked by a college-setting, popular during the time of my fieldwork. However, the central figure here is not male, but female, and not lower-caste/class, but uppercaste/class. This movie takes us back to the construction of the "modern miss" that was struggled over in the politics of the beauty pageant discussed above. It reveals the specifically Kerala mediation of that larger national construction of the "young modern woman". 
In the Malayalam feature, Pavithram (Purity), Kerala-as a space of the traditional-is in trouble. This is the story of the disruptions and displacements of the traditional Nayar household (tharavadu) and lifestyle. ${ }^{39}$ The first half of the film takes place in a tharavadu-style house in a village. A baby girl has just been born to a middle-aged couple with two grown sons. The good son, played by the foremost male star of Malayalam cinema, Mohan Lal, remains in the village while the elder son, a college-educated doctor, lives in town. Tragically, the mother dies in childbirth. Unable to cope with the loss of his beloved wife, the father hands over control of the raising of his baby daughter to the good son. The daughter named Cochu ("little one") grows up living a simple, idyllic village life with her achuchetan, a term she herself has coined which combines achu (from achan, meaning "father") and chetan (meaning "elder brother"). The first half of the movie shows Cochu growing up in this space of tradition. Towards the end of this first half, the space of tradition is marked by a scene in which a traditional puberty ritual to mark the onset of Cochu's menstruation (tirantukuli) is celebrated by the women of the village. The second half of the movie shifts to the city, where Cochu has been sent to be with her childless aunt and uncle (after much debate and discussion) and where she is to attend college. The aunt immediately goes to work on Cochu, buying her skirts, jeans, and cosmetics. She instructs Cochu to stop wearing the pawada/blouse, a long, full-length skirt and blouse that mark a traditional, regional style for young women, and encourages her to go have fun. The rest of the movie follows her decline as she wins a college beauty contest and comes under the influence of a hard-drinking, rowdy bunch of male students. Eventually, she returns in disgrace to her beloved achuchetan in the village where, immediately upon arrival and as an act of contrition, she switches from her skirt to the pawada.

I present you with this brief, rather sketchy account of this popular film to give you some sense of the structure of representation that is commonly used to trope the "traditional" and the "modern" in contemporary Malayalam cinema. There is a lot that can be said about the cultural politics of this cinema. For example, film criticism has pointed to the emergence of a potent mix of patriarchy and Nayar nostalgia which is repeatedly deployed to create notions of Keraleeyatha, or a collective cultural memory defined in upper-caste, Nayar terms. Therefore, while movies of the late 1960's and 1970's might have stereotyped the collective past of Kerala in terms of a generic peasantry rooted in "village" Kerala, now that "village" is understood as the space of Nayar-ness and thereby is upper-caste and Hindu. Further, anthropological celebrations of matriliny notwithstanding, that Nayar past is rendered in decidedly patriarchal terms. As G. Arunima argues,

"As the cultural nostalgia is cast in distinctly masculine terms, so is the anxiety related to it. Memory here is often an act of gendered erasure, with Nayar women slowly and silently fading away in a world of masculine desire and intrigue." $" 40$

Nowhere is this more stark than in Pavithram, where once the mother is literally erased, Cochu becomes the object of her brother-father's prerogatives. The only remaining Nayar woman of significance is the city-bred aunt who leads her niece down a path of corruption.

As the movie demonstrates, the opposition between these styles of women's 
clothing is highly implicated in the cultural politics of discourses about Kerala's modernity. This cultural politics is framed by the familiar binary of tradition, inseparable in Kerala from the concept of nadu, and a notion of the "modern" that is predictably linked to the West. Naden — the pervasive term for "traditional"comes from the word nadu which in Malayalam usually refers to "native place" or "home". ${ }^{41}$ A profoundly locational concept, it can only be used or applied to someone who is understood to be where they do not belong. To ask somebody where their nadu is (a ubiquitous question when one is first introduced to someone) implies that they are understood to be from someplace else. In the spatial configurations of Kerala's geography, it can also refers to the "interior" or the "countryside" (naden purethu). It is in this way that nadu as "native place" comes to be taken as "village" more generically. Insofar as the term refers both to "place of origin" and the "traditional" (naden rithi-the traditional way), the adjective naden therefore can only make sense along a space-time grid that maps "native places" onto "traditional" time. And in the logic of nostalgic memory, nadu points to another place and another time. The term "modern" (the English term is used) is a very similar term. Conventionally understood as the marker of a temporal break, the mutual imbrication of the projects of modernity and colonialism has produced a space-time dynamic where the relations between the West and the non-West are mapped onto a distinction between the past and a present-future. So, "modern" simultaneously refers to that present-future and the "West". Thus, an anxiously modern male subject expels a pawada-clad female body from a place in the present to which it cannot with certainty belong, into a "traditional" past constituted by and also constitutive of its location in Kerala's nadu; simultaneously, a female body that is marked as incorrigibly "modern" is propelled into a dangerous "West" out there.

As I will show below, such constructions of tradition and modernity structure the ways in which young women engage new, globally-inflected spaces of consumption. As in the rest of India, the beauty industry in Kerala is thriving. From the proliferation of beauty parlors, to the presence of fashion shows at almost any youth or college festival, the practices of fashion and beauty have come to redefine what constitutes femininity for middle-class young women. It is within this context that the Miss Kerala pageant was staged in the mid 1990's in Thiruvananthapuram, the capital city of the state.

The contest was but one of several Miss Kerala pageants held in various parts of the world. Held under the aegis of the World Malayalee Federation, along with Miss Keralas from such far-flung places as Abu Dhabi, London, Chicago, and Houston, the Thiruvananthapuram Miss Kerala would travel to New York for the final level of competition, thereby mapping Kerala's own diaspora. The contest was held in a large auditorium in a palace of the former Maharajah of Travancore, a Nayar royal family. Consistent with its location, the beauty contest went on to define a hegemonic Kerala femininity in line with its upper-caste Nayar trappings. The contest had some very precise specifications. There were to be three rounds, each with a different style of dress. In the first round, the contestants wore the pawada/blouse combination. In the second round, they wore the sari, most of them a Kerala sari, distinguished by white cotton cloth and 
gold thread borders. For the third round, the young women wore the mundum/ neerthu, a two-piece garment worn to resemble a sari. It is the traditional attire of mature, upper-caste Nayar women.

In each round, they were asked questions by a local television celebrity. The questions were quite specific, focusing on Kerala dance, drama, poetry, history, and literature. In round three, the round in which they wore the mundum/ neerthu, they came out one by one, carrying a large villaku (lamp), in the Kerala style, which they carefully carried to the front of the stage and lit (as one contestant put it, "It was really heavy."). This mirrors the lighting of the lamp by brides during Nayar marriage ceremonies.

Gita, a young woman who was in the audience, stated:

OK so this is what they thought. She should look like a Kerala girl. The typical Nayar. People consider that to be the middle, you know not the highest caste ... And it's not the lowest where poverty comes. It's for the middle class people. With the pawada and blouse, the long hair. You get the picture? That's the way it is, in the Nayar class.

In describing to me what she thinks the organizers were looking for, Gita links Kerala with Nayar, the "middle", long hair and the pawada. This nostalgic production of a specifically Nayar femininity is in line with a broader movement of cultural remembering defined in upper-caste, Nayar terms. However, within the rubric of the global Miss Kerala competition, the Miss Kerala from Kerala is but one of many the world over. She has an equivalent position with respect to other Miss Keralas. Her Kerala-ness is not privileged with respect to the diaspora; in fact, her equivalence with them is required by a certain cultural politics of globalization. The structure of a globalized middle class makes it possible for there to be equivalence between the likes of a Miss Kerala from Kerala and a Miss Kerala from New York. The contest reveals starkly the production of locality on a global stage. Miss Kerala must be a naden pennu in her dress, comportment, and knowledge. Written onto the female bodies of a proliferation of Miss Keralas, the nadu, locality itself, becomes transportable and transposable.

So far, I have presented an analysis that would trace the body of the woman as object, tradition commodified; a body inscribed and consumed by a patriarchal middle-class masculine gaze. But in many ways, the Miss Kerala pageant was seen as a failure. In order to examine why this is so, we must move from the structure of the event to its performative aspects. The beauty contest can be conceptualized as a literal and figurative stage for the enactment of gendered identities. Judith Butler points to the possibility of a breakdown of replicability-a "failure to repeat", as a way of understanding gender identity as a real but tenuous construction. ${ }^{42}$ It then becomes possible to view a woman's body as not simply inscribed and commodified, but also performed and enacted.

During the public performance of gender identity that took place during Thiruvananthapuram's Miss Kerala contest, certain dissonances emerged. The main problem occurred during the questioning. In short, all ten contestants had trouble handling questions about Kerala history, poetry, literature, dance and drama mainly because they simply did not know the answers and sometimes because they did not know the highly Sanskritized Malayalam necessary to answer. The problem became particularly acute during the third round. After walking 
slowly across the stage with the traditional lamp, laying it down, lighting, and then walking over to the questioner, all that many of the women could say, when asked who had won the Kerala Sahitya Akademi (a government-sponsored literary organization) award for poetry two years prior was "Sorry, I don't know." At which point the audience, laughing and heckling, would shout back, "Then why did you come?" or "Go home girl!" It became comically clear that there was a mismatch.

I asked Gita her assessment of the problem. She stated,

They felt this is what Kerala is about. And we need a girl who is about Kerala. But they forgot that there is no one like that. Do you understand that? There is no one like that who is going to get up and go on stage ... [M]ost of them had done these things before, I mean other modeling things. I'm sure they thought this was going to be one of those things. Like other contests. They have easy questions. You know, like "What do you think women should do?" Most of them had some title, Miss Coimbatore, Miss Ernakulam. One girl was in the movies. So, they walked like they were in a fashion show, except they were wearing a pawada.

For Gita, the source of the mismatch is a contradiction between form and content. The form of the pageant is part of a whole repertoire of practices-acting, modeling, fashion shows-which constitute new, globally-inflected "modern" feminine consumer spaces. A form of publicity that only "certain girls" engage in, the "modern middle-class miss" as characterized by Brinda Karat. The content required a performance of the "traditional" comportment and habitus in a public space which collided with other ("modern") bodily demeanors—walking as in a fashion show, but somehow doing so while wearing a pawada. Gita went on to say,

I was laughing, they [people in the audience] were laughing. It was so bad. But I don't blame them. They didn't know the answers. And the Malayalam. See they make fun of it because the kids just don't know. Do you blame them? Some Malayalam words are really difficult. Because it is like when you ask a kid to talk in really high-tech English; it's hard too.

She is in many ways articulating an imbrication between two structures of patriarchy. One is rooted in the patriarchal family formed through India's colonial and then postcolonial, nationalist modernity into a binarism between tradition and modernity. This intersects with the patriarchal structures of emergent, globally inflected spaces of public consumption which commodify women at the same time that they target them as consumers. This young woman struggles to articulate a sense of agency, albeit a consumerist sense of agency within this mutual imbrication. She goes on to state,

They say fashion is bad. So they have the girls wear the pawada, the sari, and all that. But what's wrong with fashion? I'm not saying fashion is a big deal. I don't say like other girls, you know. In the magazines the girls say "Fashion is a really important part of my life". I don't say that. Its just a little fun. That's all it is, just fun.

It is difficult to formulate precisely how one can rescue the "fun" of fashion from its simultaneous demonization by the protectors of "tradition" and by critics of 
capitalism who locate "fun" as a mere diversion, a market-driven, consumer, middle-class subterfuge. In this beauty pageant, the failure of the replicability of gender identities is founded on a collision between highly spatialized notions of tradition/modernity, India/West as they intersect when young women's bodies wrapped in clothing commodities move across the stage of beauty.

The idea of "fun", marking experiences of pleasure, desire, and leisure, then, becomes one lens through which to understand the differential relationship that young women and men have to new, globally-inflected consumer spaces. If we go back to the idea of "chethu", understood as a masculine, fun-loving, consumer identity, and compare it to the ways in which the young woman above struggles to articulate her desire for "fun", it becomes clear that the spacio-temporal grids that underlie these two notions are very different. The ephemerality of "chethu", located as it is in the here and now, marked by its explicit rejection of the future, unburdened by a sense of the past, shapes the roving, fun-loving, persona of a young man in his jeans, riding his motorbike, drinking beer. This is a lower-class/caste masculine consumer identity marked by desire and aspiration. The "modern miss", interested in fashion shows, modeling, beauty pageants, is a middle-class object of desire that must ultimately be tamed and disciplined. Burdened by tradition, preyed upon by modernity, she must learn to navigate these new spaces of consumption respectably and modestly. Her notions of "fun" are situated in and through notions of tradition and modernity, public and private that make her claim on these new consumer spaces tenuous. ${ }^{43}$

\section{Conclusion}

As an index of the new global order, easy associations among youth, consumption, and globalization obscure more than they reveal. In contrast to popular and some scholarly accounts, globalization is not straight-forwardly a story of homogenization. However, a recourse to the "local" erases the forms in which globalization is apprehended. If one pays attention to discourses of consumption and the cultural-political fields into which consumption as a marked site of activity, desire, and agency is inserted, the postcolonial engagements with globalization come into view. An analysis of how young people in Kerala apprehend and negotiate new globally-inflected spaces of consumption reveals these spaces to be structured by specifically post-colonial preoccupations about tradition and modernity that have differential consequences for young women and men. These spaces have created new consumer identities, for example the lowercaste male marked by consumerism and fashion, and reworked the respectable, middle-class woman as aggressively sexual, confident, and public. However, the negotiation of these new sites of consumer agency must be understood in the long-standing engagement with colonial and nationalist preoccupations with modernity that mark postcolonial locations.

Graduate School of Education

3700 Walnut Street

Philadelphia, PA 19104-6216 


\section{ENDNOTES}

1. The fact that "Americanization" is often indexed by cultural forms associated with specifically African-American cultural production speaks to the centrality of and saturation of American popular culture by black cultural forms.

2. See Peter Stearns' conclusion to this volume. He discusses the continuities and discontinuities with earlier experiences of modernity/modernization.

3. Arguably, it is the very focus on youth as a category of consumption which inaugurated British Cultural Studies. See Stuart Hall and Tony Jefferson, eds., Resistance Through Rituals: Youth Subcultures in Post-War Britain (London, 1976) and Dick Hebdige, Subculture: The Meaning of Style (London, 1981). As Grew, in this volume, notes, an earlier preoccupation with youth as political actors gave way to the more contemporary focus on youth and consumption.

4. See for example, Tracey Skelton and Gill Valentine, eds., Cool Places: Geographies of Youth Cultures (London, 1998), Vered Amit-Talai and Helena Wulff, eds., Youth Cultures: A Cross Cultural Perspective (London, 1995), Mark Liechty, Suitably Modern: Making Middle Class Culture in a New Consumer Society (Princeton, 2002), a special issue of Signs: Journal of Women's Studies edited by Kum-Kum Bhavnani, Kathryn Kent, and France Winddance Twine, on "Feminisms and Youth Culture" (Chicago, 1998), Sunaina Maira and Elisabeth Soep, eds., Youthscapes: The Popular, The National, The Global (Philadelphia, 2005).

5. See Arjun Appadurai, Modernity At Large: The Cultural Dimensions of Globalization (Minneapolis, 1996) and Aihwa Ong, Flexible Citizenship: The Cultural Logics of Transnationality (Durham, 1999).

6. For a focus on consumption within the discipline of anthropology that pre-dates its link with globalization, see Arjun Appadurai, ed., The Social Life of Things: Commodities in Cultural Perspective, (Philadelphia,1988). Arjun Appadurai pays close attention to the links between consuming practices and globalization in Modernity At Large: The Cultural Dimensions of Globalization (Minneapolis, 1996). Mark Liechty examines the impact of consumerism and its intersections with globalization in the Nepali context in his ethnography Suitably Modern: Making Middle Class Culture in a New Consumer Society (Princeton, 2004). Within the field of social history and the intersection of anthropology and history, studies of consumption in world-historical context abound. See Peter Stearns, Consumerism in World History: The Global Transformation of Desire (London, 2001) and Sidney Mintz, Sweetness and Power: The Place of Sugar in Modern History (New York, 1985).

7. See Hall and Tony Jefferson, eds., Resistance Through Rituals and Hebdige, Subculture. For a feminist critique of this work see Angela McRobbie, Feminism and Youth Culture: From Jackie to Just Seventeen (London, 1991). See also, Daniel Miller, Acknowledging Consumption: A Review of New Studies (London, 1995).

8. For an overview of such arguments, see Arjun Appadurai, "Introduction: Commodities and the Politics of Value" in The Social Life of Things: Commodities in Cultural Perspective (Philadelphia, 1988) 3-63.

9. For Zimbabwe, see Timothy Burke, Lifebuoy Men and Lux Women: Commodification, Consumption and Cleanliness in Modern Zimbabwe (Durham, 1996). Two books that focus 
on clothing and fashion include Hildi Hendrickson, Clothing and Difference: Embodied Identities in Colonial and Postcolonial Africa (Durham, 1996) and Emma Tarlo, Clothing Matters: Dress and Identity in India (Chicago, 1996).

10. Appadurai, Modernity At Large, 42.

11. See Chua Beng-Huat, Consumption in Asia: Lifestyles and Identities (London, 2000), 19.

12. Rita Felski explores the place of the feminine within modernism through the imagining of the consumer as a feminine Other in her book The Gender of Modernity (Cambridge, MA, 1995). Kathy Peiss provides a sensitive account of young working women's leisure and consumption practices in turn-of-the-century New York in her book Cheap Amusements: Working Women and Leisure in Turn-of-the-Century New York (Philadelphia, 1987). For the role of consumption in contemporary girls' youth culture, see McRobbie, Feminism and Youth Culture, Mica Nava, Changing Cultures: Feminism, Youth, and Consumerism (London, 1992) and Signs: Journal of Women's Studies, a special issue on "Feminisms and Youth Culture." A focus on girls and young women in postcolonial contexts is rare. For an exception see Ida Fadzillah, "The Amway Connection: How Transnational Ideas of Beauty and Money Affect Northern Thai Girls' Perceptions of Their Futures" in Maira and Soep, eds., Youthscapes, 85-102.

13. See, for example, Carol Breckenridge, ed., Consuming Modernity: Public Culture in a South Asian World, (Minneapolis, 1995), Satish Deshpande, Contemporary India: A Sociological View (Delhi, 2003), chapter 3, Tejaswini Niranjana, "Introduction" to "Gender, Media, and the Rhetorics of Liberalization", special issue of the Journal of Arts and Ideas, Nos. 32-33, 1998.

14. As Deshpande argues, consumption and commodities were important during earlier periods of modern Indian history, for example during the height of the Swadeshi (self-rule) movement when rejection of foreign goods became part and parcel of the anti-colonial struggle. As he points out, the ideological meanings of consumption in this regard were under the sign of "patriotism", service, and sacrifice for the nation. Today, under contemporary conditions of globalization, consumption has taken on a new ideological charge, a projection of India onto the global stage. See Satish Deshpande, Contemporary India: A Sociological View (Delhi, 2003), chapter 3.

15. K.P. Kannan and K.S.Hari, "Kerala's Gulf Connection: Emigration, Remittances and their Macroeconomic Impact 1972-2000", Centre for Development Studies, Working Paper 328, March 2002.

16. See Purnima Mankekar, Screening Culture, Viewing Politics: An Ethnography of Television, Womanhood, and Nation in Postcolonial India (Durham, 1999) and William Mazzarella, Shoveling Smoke: Advertising and Globalization in Contemporary India (Durham, 2003).

17. See Partha Chatterjee, "Colonialism, Nationalism, and Colonized Women: The Contest in India" in American Ethnologist 16: 622-633 and Kum-Kum Sangari and Sudesh Vaid, Recasting Women: Essays in Indian Colonial History, (Delhi, 1990).

18. See Malathi De Alwis, 1995, "Gender, Politics, and the 'Respectable Lady"' in Unmaking the Nation: The Politics of Identity and History in Sri Lanka, eds. P. Jeganathan and Q. Ismail (Colombo, 1995) and Himani Banerjee, "Attired in Virtue: The Discourse of 
Shame (lajja) and Clothing of the Bhadramahila in Colonial Bengal" in From the Seams of History: Essays on Indian Women, ed. Bharati Ray (New Delhi, 1995).

19. See Mary John, "Globalization, Sexuality, and the Visual Field: Issues and non-Issues For Cultural Critique" in Mary John and Janaki Nair, eds., A Question of Silence? The Sexual Economies of Modern India (Delhi, 1998) and Niranjana, "Introduction."

20. USA Today, May 18, 2000.

21. Ibid.

22. Ibid.

23. Outlook, May 29, 2000.

24. The details of the Miss World pageant that follow are taken from "Pageant and Protests: A Miss World show under state protection" by Parvathi Menon, Frontline, December 13, 1996.

25. Outlook article.

26. Ibid.

27. See Mazzarella, Shoveling Smoke.

28. For discussions and analysis of these protests and positions, see Nivedita Menon, "Refusing Globalization and the Authentic Nation: Feminist Politics in the Current Conjuncture" in Economic and Political Weekly, January 3, 2004.

29. Frontline, December 13, 1996.

30. Ibid.

31. See John, "Globalization, Sexuality, and the Visual Field." Niranjana argues that we focus on the burden of authenticity placed on the female form, particularly the "normed upper-class female body." Following this, I emphasize the spacio-temporal matrix that "locates" this female form.

32. See Niranjana, "Introduction," 7.

33. See John, "Globalization, Sexuality, and the Visual Field."

34. Within the development literature, Kerala is understood to be a highly successful "model". For a discussion and overview of the characteristics and contradictions of this model, see Govinda Parayil, Kerala: The Development Experience, Reflections on Sustainability and Replicability (London, 2000).

35. See Vivek Dareshwar and Tejaswini Niranjana, "Kaadalan and the Politics of Resignification: Fashion, Violence and the Body" in Journal of Arts and Ideas (New Delhi, 1996)

36. Filippo Osella and Caroline Osella, briefly mention this term but do not examine its gender specificities "From Transience To Immanence: Consumption, Life-Cycle And Social Mobility In Kerala, South India,” Modern Asian Studies, vol. 33, no. 4 (1999): 989-1020. 
37. This is the largest caste in Kerala. For a recent discussion of the experience of social mobility of this formerly untouchable caste, see Filippo Osella and Caroline Osella, Social Mobility in Kerala: Modernity and Identity in Conflict (London, 2000).

38. These are elite private schools of national repute.

39. Nayars are the historically dominant landholding caste in the region. This caste and its matrilineal arrangements have been well-studied in the anthropological literature. See David Schneider and Kathleen Gough, Matrilineal Kinship (Berkeley, 1961), and C.J. Fuller, The Nayars Today (London, 1976). For a historicization of the anthropological construction of Nayar kinship, see G. Arunima (1992). For a broad historical overview of Nayar social reform, see Robin Jeffrey The Decline of Nayar Dominance: Society and Politics in Travancore, 1847-1908 (Delhi, 1994).

40. See G. Arunima, "Matriliny and its Discontents" in India International Centre Quarterly-Kerala: Progress and Paradox (Summer, 1995): 157-167. For a discussion of Kerala's matrilineal past, see G. Arunima, There Comes Papa: Colonialism and the Transformation of Matriliny in Kerala, Malabar c. 1850-1940 (New Delhi, 2005).

41. For a discussion of the term nadu in Tamil see Valentine Daniel, Fluid Signs: Being a Person the Tamil Way (Berkeley, 1987). He too stresses its locational character.

42. Judith Butler, Gender Trouble: Feminism and the Subversion of Identity (London, 1990).

43. It is worth noting the presence of the lower caste/class male, the upper caste/class female, and the upper caste/class male as sites of consumer agency/desire in popular cultural representations (though I do not discuss the latter in this article). What is absent, in this structure of representation, is the lower class/caste female as a site of consumer agency/desire. 